\title{
Medicare for the Poor in India: An Ailing Prescription
}

\section{Nidhi Nalwaya and Rahul Vyas}

Pacific Business School, Pacific School of Law, Paher University, Rajasthan 313001, India

*Corresponding author: Rahul Vyas, Pacific Business School, Pacific School of Law, Paher University, Airport Road, Pratap Nagar, Udaipur, Rajasthan 313001, India, Tel: +919829855566; +919309273192; E-mail: rahulv09@gmail.com

Received date: June 03, 2017; Accepted date: June 26, 2017; Published date: June 30, 2017

Copyright: @ 2017 Nalwaya N, et al. This is an open-access article distributed under the terms of the Creative Commons Attribution License, which permits unrestricted use, distribution, and reproduction in any medium, provided the original author and source are credited.

\section{Commentary}

The startling facts revealed during the recently held "Aanganwadi, Phulwadi Pakhwada" in April 2017 in the mostly Tribal, Salumber district in South Rajasthan where reportedly more than 18 girl children below the age of 5 years were diagnosed as suffering from Cardiac diseases, Mental disease, Blindness, etc. also many serious cases of malnutrition came to light which were reported at Jodhpur Khurd by a regional newspaper. These recurrent and widespread disclosures have put a heavy shroud of misgivings over the state of public health sector in the rural areas especially the tribal belts.

These incidents raise serious questions about the quality and extent of Medical services accessible to the rural $\mathrm{BPL}^{*}$ and poorer sections of the society. The moot point here being, in spite of the setting up of $\mathrm{CHC}^{* *}$ and $\mathrm{PHC}^{\star * *}$ and sub centres and a host of other initiatives taken up by the Health Ministry both at the Central and State level, the pathetic state of affairs vis a vis rural health care is alarming to say the least.

Public health services are theoretically separate from medical services. They have their basic task cut out as: a) The reduction in a population's exposure to disease occasionally through assuring food safety and other health regulations; b) Vector control; c) The monitoring of waste disposal and water systems; and d) The imparting of health education to develop better personal health/ hygiene habits.

The government's objective to establish Sub Centers, PHC's and CHC's in the rural areas as well as hilly and tribal areas have been laid to shambles as more damning figures emerge regarding the collapse of rural healthcare services concerning the breakout of and reported deaths due to Encephalitis, Chicken Pox, Viral Meningitis et al. As far as the issue of disease prevention and treatment is concerned, a lot is still left to be done, particularly as we read about the rising number of reported deaths due to incidents of Dengue, Malaria, and Chikungunya which have been going up at a fast clip especially in the rural areas.

- *Below Poverty Line.

- ${ }^{* *}$ Community Health Centre.

- $\quad{ }^{* * *}$ Primary Health Centre.
The shocking loss of confidence of the common man on the public sector health care services is a wakeup call for the powers that be, but far from providing succor through increased funding for the public health care system, the health care spend stands at a bare minimum of our GDP, far below the World Health Organization's recommendations. As per the National Health Profile 2017 (Central Bureau of Health intelligence, Ministry of Health and Family WelfareGovt. of India), figures the public expenditure on health as a percentage of GDP is currently at $1.4 \%$ which is much lower than even Low Income countries as per figures of the World Bank Income Groups report 2016. Moreover, the Centre: State share in total public expenditure on health was 33:67 in 2015-16, to make matters worse the share of the union allocations have been consistently on the wane.

The systematic undermining of public health care system by the successive governments has reduced the health care sector in the country to a mere skeleton.

The NHP (National Health Policy) 2017 further aggravates the situation, marking a clear shift which now allows the private sector to gain a heavy hand in the public health care space. The proposed move "from primarily public services to new, strategic partnerships with private health providers" ostentatiously to fill the gaps in public and private services in health care is glaring in its ignorance of the public sector which should ideally be in the driver's seat of the nation's health care system but is being pushed to the brink through systemic apathy, albeit in reality it is the public sector which is shouldering the burden of basic minimum health care and national health programmes (Mission Indradhanush, IDSP etc.), health information systems and a wide range of other services.

Globally, be it the NHS (National Health Services) in UK or the analogous systems prevalent in Brazil, South Africa et al, the dispensation in power had a structural leverage of control over the health sector as contrasted with our country where about $75 \%$ of this is already in the private sector, thus making us achieve the dubious distinction of being the nation which has the highest ratio of privatized health sector in the world.

\begin{tabular}{|l|l|}
\hline Private sector health care system in India & Percentage \\
\hline Medical Graduates & 90 \\
\hline PG Doctors & 95 \\
\hline Outpatient Care & 80 \\
\hline Indoor Patient & 60 \\
\hline Medical Colleges & 30 \\
\hline
\end{tabular}

Table 1: 2014: As per the Jan Swasthya Abhiyan (JSA). 
The adverse effect of this is all too obvious in the rural areas where the expenses occurred on medical care are more than $10 \%$ of the family expenditure as reported by the NSSO 71st round report. Inter alia this leads to a situation where the rural populace has to dish out a whopping Out of Pocket Expense (OOPE) for health care again as per NSSO 71st round more than $60 \%$ of OOPE on health expenditure is on medicine, the JSA (Jan Swasthya Abhiyan) estimates that about forty million people are pushed below the poverty line annually due to this expense alone. Adding fuel to the fire is the fact that availing Health Insurance remains a distant dream for the rural people.

In this context the, Rajasthan Jan Swasthya Abhiyan has taken strong exception to the notification "Policy to promote private Investment in Health Care facility (amendment) 2011" issued by the Rajasthan State Government revising the fee charged by various categories of government doctors and nursing staff for private practice and demanded its immediate withdrawal. The new rules would lead to complete privatization of health services vide the Policy to Promote Private Investment in Health Care Facilities. Given that the Maternal Mortality Ratio (MMR) in Rajasthan at 318 and Infant Mortality Rates (IMR) in Rajasthan at 48 as per the censusindia.gov.in are in themselves very high, promotion of private healthcare services is a precarious trend for a State already experiencing such gloomy status of health.

A study by National Health Mission (Ministry of Health and Family Welfare) in 2016 shows that in Rajasthan there is a shortfall of $25 \%$ in PHC's, $26 \%$ in sub centers and 35\% in CHC's. The Doctors required at the PHC's are in position but PHCs themselves are short of the required number. This state of the health sector should be reversed. The private sector does have a role to play in the health care industry but even in China the medical services provided are managed predominantly by the public sector. Incidentally the most effective health systems in the world as in Thailand, Cuba, and Singapore etc. have a large contribution by the public sector.

Medical Tourism and other hi tech Medico clinical interventions as projected in the NHP 2017 are all fine statements of intention but the common man is still in the woods. The NHP falls flat on the balance that needs to be exercised between the preventive and curative components of health care whereas the NHP 2017 is heavily skewed towards Private partnerships for secondary and tertiary services.

\section{Health Insurance}

Health Insurance is a means for improving healthcare utilization, reducing the escalating healthcare cost and protection of households against high medical expenses. The components of the current health insurance are Employer mandated SHI (Social Health Insurance), Commercial /Voluntary health insurance and target oriented GFHI (Government Funded Health Insurance).

A host of Health insurance schemes galore-ESIS (Employee State Insurance Scheme), CGHS (Central Government Health Scheme), Commercial health insurance provided by public and private owned companies, Karnataka-Yashasvini Cooperative farmers healthcare scheme, AP-Rajiv Arogyashri Community Health Insurance, RSBY
(Rashtriya Swasthya Bima Yojana), HP-RSBY plus, RajasthanBhamashah Swasthaya Bima Yojana.

Insurance Schemes like RSBY (Rashtriya Swasthya Bima Yojana), a central government sponsored scheme and many more like the Rajiv Arogyasri have failed to address the issue properly because the dichotomy in the scheme's structure regarding the treatment of ailments which leaves the door open to the private health care providers to slip in another achilles heel is the insurance provided against only a set of ailments and not a comprehensive package. The government will play the role only in the preventive aspects like immunization and the potential revenue generating aspect of clinical care will be handed over to the private sector. In the light of these issues it becomes clear that Insurance Schemes in their present form and structure are not the way forward for the solution of the health care problems faced by the rural populace.

The data reveals that the private insurance providers in the health space in the Family/Floater policies have notched up an impressive lead over the public sector insurers. The composite data points out that the private sector insurers are commanding an average premium of Rs. 662 as compared to Rs. 518 of the public sector insurers even while the private players cover a limited number of ailments. Though they offer less number of schemes the premium charged per capita is higher.

The health insurance schemes largely benefit the private sector participants via the modus operandi, which entails financing through public (Taxpayer's Money) and treatment by both public and private hospitals. The structural bias makes sure that the private sector garners the maximum share, rubbing salt into the wound is the fact that insurance is provided only against a specified set of ailments. The fallout has been that the private sector participants inflate the bills by prescribing unnecessary diagnostic tests, investigations, medication and even surgery.

In conclusion it seems that a long haul awaits the poor to avail of a benign medicare system which is affordable and accessible, what with the fact that as per Table 1 the private sector health care system in the country controls $30 \%$ of the Medical colleges but a whopping $90 \%$ of medical students graduate from these Colleges even the Outpatient Care is at $80 \%$. Moreover, the draft NHP 2017 is biased towards the PPP model.

A case in point being the Rajasthan Government's Bhamashah Health Insurance Scheme for which the State Government has allocated Rs. 3.7 billion and has signed on the New India Assurance Company but the insurance scheme itself provides an option for patients to avail the services of public or empanelled private hospitals leaving the ground wide open for private players to have a field day, even as the charges levied by private sector hospitals are much higher, to make matter worse the private health care service providers can prescribe branded medicines as per the state Essential Drug List (EDL) and do not have to strictly adhere to the generics, at hindsight it's apparent that all these measures are but just a tactic to prop up the private health care sector in the state.

There is a crying need to redesign, rehaul and rethink the medicare system for the poor which is comatose itself and in no way can in its present state help in the achievement of the World Health Organization's (Universal Health Coverage) UHC goals. 